\title{
Improved culture of individual muscle fibres with and without spinal cord explants in a collagen gel
}

\author{
Jeanne C Jay and Kate F Barald

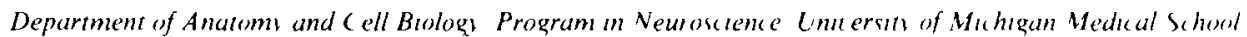 \\ $4 n$ Arbor $M I 48109(L S A)$
}

(Recelved Juk 9th 1985 ,

(Revised September 23rd 1985)

(Accepted September 28th 1985)

Kes nords culture - muscle fiber - collagen - adult mammalıan muscle - nerse-muscle coculturc

Suspension culture of single adult rat flexor digitorum brews (FDB) muscle tibrew in Vitrogen a purilied collagen on tissue culture plastic or glass with mesh ring supports is supersor to culture upon other substrates including collagen- lamınn- or Vitrogen-coded tissue culture plastic The Vitrogen gel-tibre mixture which attaches to glass or plastic provides at least 10 times more fibres per dish than does plating fibres on other substrates Use of Vitrogen gel permits variable platıng densities and the production of adequate numbers of cultures for long-term experimental comparisons of acetykholinesterase (AChE) and rhodamine- $\alpha$-bungarotoxin (RBTX) distribution on muscle fibres Lse of $40 \mu \mathrm{g} / \mathrm{ml}$ ovotransferrin (OT) instead of chick embrvo extract in the culture medium significantls improves long-term survival Cultured fibres with or without the addition of ventral spinal cord explants may also be examined with electrophviological techniques

Several techniques have been developed for culturing single denervated adult skeletal muscle fibres such as those of the rat flexor digitorum brevis (FDB) Fibres have been plated on collagen (Beckoff and Betz, 1977b), on layers of fibroblasts stabilized by exposure to gamma radiation (Rubin et al , 1979), on beds of 7-day-old chick skın fibroblasts (Gundersen, unpublished), and in fibrin clots (Bischoff, 1975) No data on the number of viable fibres plated or investigation of viability with time were mentioned in these studies, but small numbers of fibres (1-2\%) (Bischoff 1979) were apparently viable for up to 3 weeks We adapted a technique of Bischoff' suspending fibres in a Vitrogen gel (Grega and Jay, 1983) Subsequently our method was used by Stya and Axelrod (1984) to examine acetylcholine receptor mobilıty on limited numbers of cultured adult fibres maintaıned for 14 days Agan no viabilıts data were reported in this study

Correspondence KF Barald Department of Anatom and Cell Bololot Program in Veuroxcience University of Michigan Medical School Ann Arbor MI 48109 USA 
We report here good survival of muscle fibres cultured alone or with preces of the ventral halves of spinal cord explants in Vitrogen gels Adherence to glass surfaces was greatly improved by addition of a Nitex mesh ring Substitution of ovotransferrin $(40 \mu \mathrm{g} / \mathrm{ml})$ for chıck embryo extract also significantly improved survival in the second week of culture This technique provided long-term stability of large numbers of fibres for up to $2 \frac{1}{2}$ weeks Experimental assessment of acetylcholinesterase (AChE) and acetylcholine receptors (AChRs) with histochemical or fluorescent labels was then possible on fibres maintained in culture for long tıme periods

Two FDB muscles were first treated with collagenase by following a procedure simılar to that used by Beckoff and Betz (1977a,b), collagenase digested the connective tissue and tendinous insertions of skeletal muscle without affecting membrane and electrical properties or acetylcholıne sensitivity (Betz and Sakman, 1973, Beckoff and Betz, 1977a), apparently the basal lamina remained intact (Bischoff, 1979) Single fibres which remained suspended in the dissociation solution were removed and transferred to a nutrient medium (Barald and Berg, 1978) containing $10^{-7} \mathrm{M}$ tetrodotoxin (TTX) Muscle fibres contained in Vitrogen drops were plated on specially prepared $35-\mathrm{mm}$ tissue culture dishes with glass bottoms Rings of Nitex mesh $4 \mathrm{~mm}$ in width were cut to fit the outer edge of the dish bottom and were secured to the glass surface with hot $05 \%(\mathrm{w} / \mathrm{v})$ agarose in $3 \times$ distilled water The agarose solution was allowed to dry overnight and could be stored up to one month before addition of Vitrogen suspensions Cocultures were made with pieces (approximately $100 \mu \mathrm{m}$ ) of the ventral halves of embryonic spinal cords, explants were initially cultured by our previous method (Grega, 1984), excised, and positioned in target fields of 24-h-old muscle fibres Approximately 12 explants were excised from a 1- to 10-day-old explant culture and pipetted into a muscle fibre culture from which the nutrient medium was removed Excess liquid was drained from the culture until only a thin film remained Explants were positıoned by means of a No 5 Inox forceps in a target field of 1-6 muscle fibres All remainıng medium was removed, and a drop of Vitrogen mixture was applied to each explant or several explants which were in the same vicinity Cocultures were placed in a humidity chamber which consisted of a lidded glass dish lined with several water-soaked "lint-free" tissues (Kımwipes) Cocultures were incubated for $20 \mathrm{~min}$ at $37^{\circ} \mathrm{C}$ in a $5 \% \mathrm{CO}_{2}$ atmosphere to allow the Vitrogen to gel Nutrient medium used for muscle cultures (Barald and Berg. 1978) was applied and changed every other day

In order to compare the effects of the presence of nerve upon the distribution of muscle fibre AChE and RBTX binding sites over tıme it became necessary to establish a culture system which would yield sufficient numbers of viable fibres for investigation Culture methods other than suspending fibres in Vitrogen did not provide sufficient numbers of viable fibres (see Table 1) Plastic tıssue culture dishes were coated with one of the following Vitrogen, collagen (Barald and Berg, 1978), chick fibroblasts (Temın, 1960), chıck fibroblasts over a layer of collagen, chıck fibroblast-derıved extracellular matrıx, and laminın $\left(\begin{array}{lll}1 & 1 \mu \mathrm{g} / \mathrm{ml}, 025 \mathrm{ml} / \mathrm{d} ı \mathrm{sh})\end{array}\right.$ Fibres, which were suspended in $1 \mathrm{ml}$ of nutrient medium, were plated on these substrates and were allowed to settle overnight Medium containıng suspended fibres was removed from each dish, and fresh medium was applied Phase contrast criteria 
TABLE 1

PLATING EFFICIENCY OF VIABLE FDB MUSCLE FIBRES ON VARIOUS SUBSTRATES

Values are means + SE M

\begin{tabular}{lc}
\hline Substrates * & Percent fibre adherance \\
\hline Fibres suspended in Vitrogen & $998 \pm 020$ \\
Fibres plated on Vitrogen & $46 \pm 077$ \\
Fibres plated on collagen & $43 \pm 115$ \\
Fibres plated on chick fibrobldsts & $102 \pm 114$ \\
Fibres plated on chick fibroblasts & $79 \pm 253$ \\
grown on collagen & \\
Fibres plated on chick fibroblast- & $51 \pm 112$ \\
derived extracellular matrix ** & $50 \pm 111$ \\
Fibres plated on lamının & \\
(11 1 g/ml-0 25ml/dish) &
\end{tabular}

* Initial platıng density was $150-200$ fibres $/ 35 \mathrm{~mm}$ culture dish $\mathrm{n}=\mathbf{3}$ for each substrate tested

** Fibroblasts were plated and then removed by lysing them in $3 \times$ distilled water

(the presence of definite striations and bulging peripheral nuclei as observed by Beckoff and Betz, 1977b) were used to compare the number of viable fibres suspended in Vitrogen gels to the number of viable fibres which adhered to the other substrates after $24 \mathrm{~h}$ (see Table 1) Plating fibres in Vitrogen resulted in a 10-fold increase in plating efficiency, providing an adequate sample size (8-12 cultures $/ 2$ FDB muscles with 20-400 fibres/dish) Viability studies were carried out on cultures with a glass surface and mesh support in which $01 \%$ trypan blue was used as a viability indicator At the $96 \mathrm{~h}$ time point, of $172-390 \mathrm{f}$ bres plated per dish, $385 \% \pm 195$ (SEM, $\mathrm{n}=13$ ) of the initial population were viable In muscle fibre-spinal cord explant cocultures, which contained 173-382 fibres at the time of explant addition. 392\% \pm 249 (SEM, $\mathrm{n}=31$ ) of the fibres were viable at $96 \mathrm{~h}$ Endplate AChE and RBTX binding persisted throughout the period examined Viability was confirmed by electrophysiological intracellular recordings of -50 to $-70 \mathrm{mV}$ resting potentials (Jay et al, unpublished), these results were in agreement with those of Beckoff and Betz (1977a) Neither viability nor the distribution pattern of AChE and RBTX binding sites was affected by platıng density or coculture conditions

In order to increase the viability with time in culture an effort was made to improve the nutrient medium Although addition of ascorbic acid to the nutrient medium did not increase viability, medıum in which $40 \mu \mathrm{g} / \mathrm{ml}$ of ovotransferrın (OT) (Iı et al, 1982) was used in place of $5 \%$ chicken embryo extract (CEE) (Barald and Berg, 1978) significantly increased viability during the second week of culture In one such experıment dishes containıng between 190 and 357 fibres were maintained in either C E E or OT medium In the second week, $15 \times$ as many fibres survived in cultures with OT medium compared to cultures with C E E medium (up to $20 \%$ survival) The substitution of OT for CEE provided a better-defined medium in which to assess the effects of nerve tissue on denervated muscle fibres. since no constituents derived from nervous tissue were present 

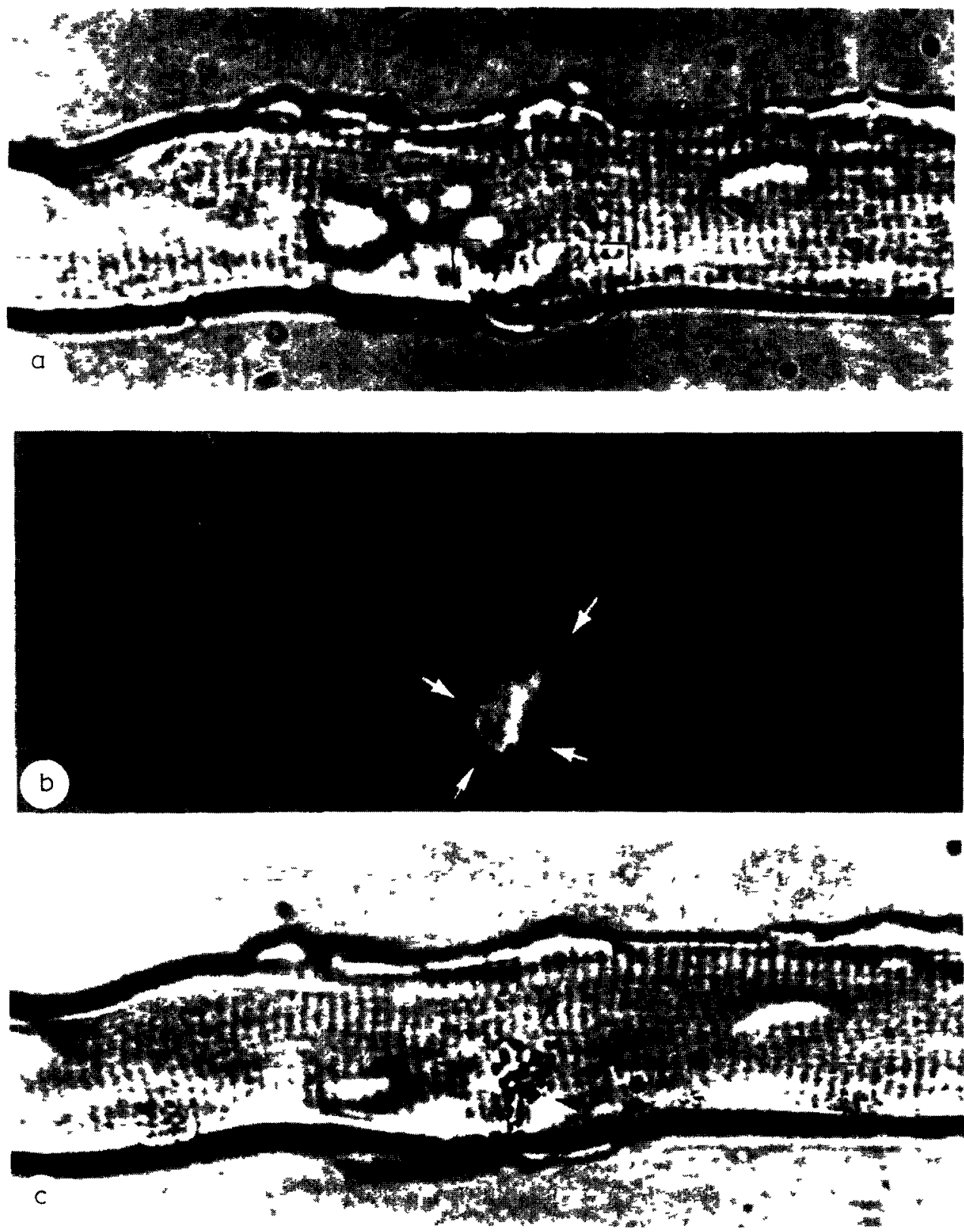

Fig I a the fibre in Fig la-c was photographed in a culture which did not contain explants Fibre vability was initially determined in such cultures by staıning with $01 \%$ trypan blue Viable fibres exclude the dve Cultures were fixed for $30 \mathrm{~min}$ in an L-15 based solution (Moody-Corbett and Cohen 1981) RBTX binding sites were fluorescently labelled and AChE was revealed histochemically Each viable fibre was examined for both RBTX binding sites and AChE The effect of the presence of nerve on the distribution of the above-mentioned parameters $w$ as then investigated in cocultures Prominent cross-striations and peripheral location of nuclei are apparent in this phase contrast micrograph of a vidble fibre fiom a 48-h-old culture a the endplate region is boxed b fluorescence micrograph of the fibre in (a) After fixation this culture $w d s$ incubated in $1 \times 10^{\circ} \mathrm{M}$ RBTX to locate putative acetylcholine receptors Note the fluorescently labelled area which is delimited by the arrow tips and marks the postivnaptic 

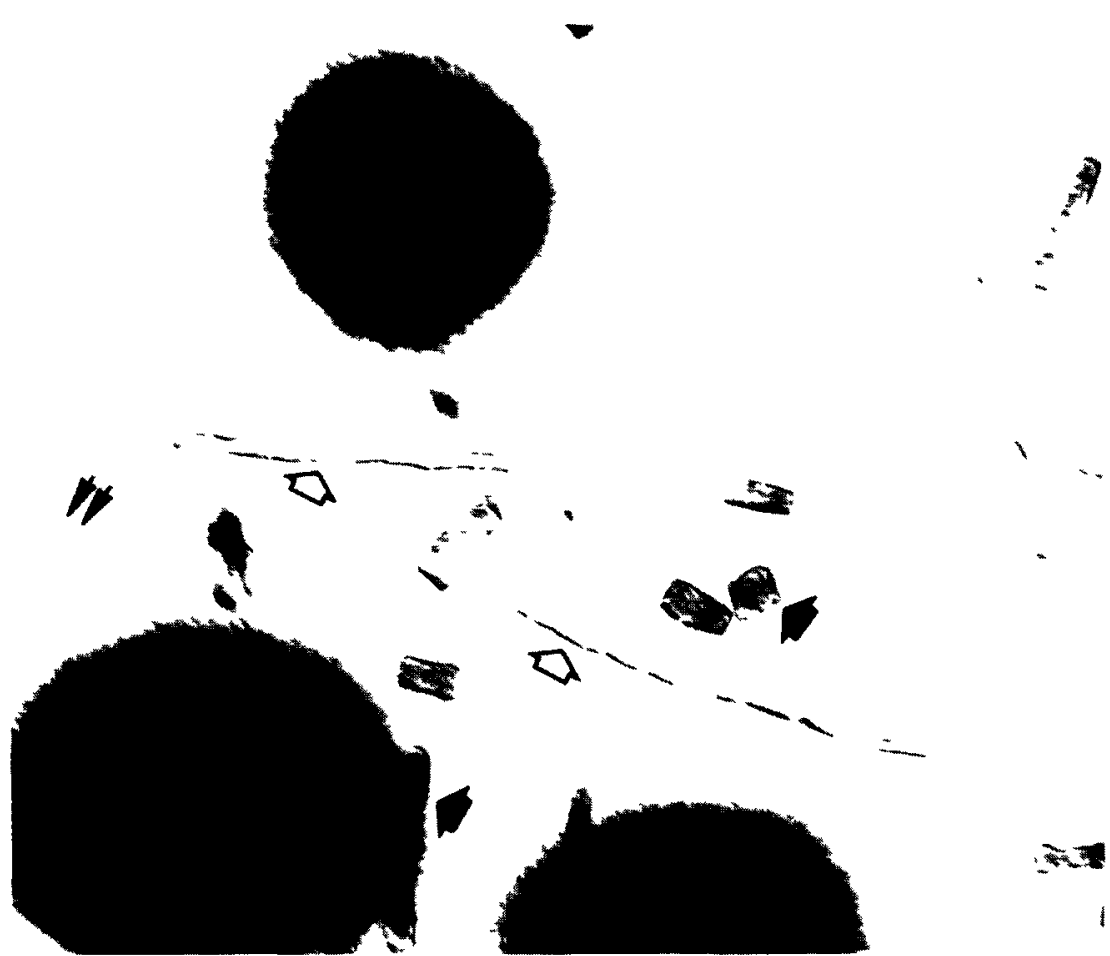

Fig 2 Pieces of ventral halves of embryonic spinal cord were placed in target tield of muxcle fibres which had been previously cultured for $24 \mathrm{~h}$ This phase contrast micrograph of a 72 -h-old coculture $\mathrm{h}$ as stained with $01 \%$ trypan blue Both nonviable fibres and fragments (filled arrows) take up the dve viable fibre, (hollow arrows) exclude it Neurites (double arrows) extend from the entire circumference of the explants and appear to contact viable muscle fibres randomly

We are currently using this in vitro system of muscle fibres \pm nerve to investigate the role of the muscle basal lamina in reinnervation and neurite behaviour with respect to individual muscle fibres The distribution of 2 basal lamina components (AChE and lamının), and 1 plasma membrane component, putative acetylcholine receptors, revealed by RBTX binding sites, is being investigated in muscle cultures and cocultures Fig 1a-c illustrates RBTX binding sites and AChE at the original synaptic site in muscle cultures A typical coculture is seen in $F_{1} g$ Intracellular electrophysiological recording from muscle in cocultures revealed irregularly appearing miniature endplate potentials (MEPPs) of 1-3 mV with a duration of $60 \mathrm{~ms} 24 \mathrm{~h}$ after the addition of explants (Jay et al, unpublished), indicating that the fibres examined were innervated Whether all nerve-muscle contact sites are functional is currently under investigation The culture procedure for individual denervated

region of the neuromuscular junction $c$ phase contrast micrograph of the fibre in (a) and (b) After incubation with RBTX this culture was treated with a modified Karnovsky stain (Moody-Corbett and Cohen 1981) to locate $A C h E$ The region which contains $A C h E$ is enclosed by arrou tups and is colocalized with endplate RBTX binding sites in (b) a b and $c 625 \times$ 
muscle fibres should prove useful for future studies of nerve-muscle interactions and degeneration and/or regeneration of various muscle components

\section{Acknowledgements}

This study was supported by an NIH predoctoral traineeship from a Developmental Biology Training Grant and by a Rackham predoctoral fellowship to $\mathbf{J} \mathbf{J}$, by a grant from the MDA to K F B , and by USPHS Grants NS 17262 and NS 17017 (subproject) to K F B We would like to express particular thanks to Dr Richard Bischoff of Washington University for demonstratıng the FDB dissection and culturing method upon which this technique is based We would like to thank the following people for providing anımals Drs G Brewer, J Schwartz, C Carter-Su, and $\mathrm{D}$ Thomas We also appreciate the anımal housing space furnished to us by $\mathrm{Dr}$ J L Claflin We thank Dr S F Barry for assistance with the electrophysiology and Dr D S Grega for help with some of the early experiments We would also like to thank M Velez, L Polacek, E Coucouvanıs, C Lam and F Lin for help with media and glass dish production for tissue culture preparations We appreciate comments on the manuscript which were made by Drs RE Must and R Stevens, G Phillips and $S$ Sweet

\section{References}

Barald, K F and Berg, D K (1978) High affintty choline uptake by spinal cord neurons in cell culture Dev Biol , $65 \quad 90-99$

Beckoff, A and Betz, W J (1977a) Physıological properties of dissociated muscle fibres obtained from innervated and denervated adult rat muscle $J$ Physiol (London), 271 25-40

Beckoff, A and Betz, W (1977b) Propertıes of isolated adult rat muscle fibres maintained in tissue culture, J Physiol (London), 271 537-547

Betz, W and Sakmann, B (1973) Effects of proteolytic enzymes on function and structure of frog neuromuscular junctions, J Physiol (London), 230 673-688

Bischoff, R (1975) Regeneration of single skeletal muscle fibres in vitro Andt Rec $180 \quad 645-662$

Bischoff, R (1979) Tissue culture studies on the ongin of myogenic cells during muscle regeneration in the rat In A Mauro et al (Eds), Muscle Regeneration, Raven Press New York, pp 13-29

Grega, D S (1984) Culturıng spınal cord explants in a collagen gel J Neuroscı Meth 11 199-203

Grega, D S and Jay, J J (1983) Adult mammalian muscle fibres cultured in the absence and presence of neurons Soc Neurosci Abstr, 9(1) 344

Gundersen, $R$ Reinnervation of isolated adult muscle fibres in vitro, unpublished

I1 I, Kimura, I and Ozawa E (1982) A myotrophic protein from chicken embryo extract its purification, identity to transferrın, and indispensibility for avian myogenesis, Dev Biol 94 366-377

Jay, J J and Barald, KF, The distribution of acetylcholınesterase and rhodamıne alpha-bungarotoxın binding sites on adult mammalian muscle fibres cultured in the absence and presence of nerve tissue, unpublished

Jay J J, Barry S F and Barald, K F, Reinnervation of individual adult muscle fibers in coculture unpublished

Moody-Corbett, F and Cohen, MW (1981) Localızation of cholinesterase at sites of high acetylcholine receptor density on embryonic muscle cells cultured without nerve, J Neurosci, 1(6) 596-605

Rubin, L L, Keller, C E and Schuetze, S M (1979) Satellite cells in isolated adult muscle fibers in tissue culture In A Mauro et al (Eds), Muscle Regeneratıon, Raven Press New York, pp 281-284

Stya $M$ and Axelrod D (1984) Mobilıty of extrajunctıonal acetylcholıne receptors on denervated adult muscle fibres $J$ Neurosci, 4(1) 70-74

Temin, H M (1960) The control of cellular morphology in embryonk cells infected with rous sarcoma virus in vitro Virology, $10 \quad 182-197$ 